\title{
ON TIME EXPRESSIONS IN MYCENAEAN GREEK
}

\begin{abstract}
Time expressions in Ancient Greek are versatile regarding their form, since the semantic role of Time in this language, like in other Indo-European languages is expressed with several different cases. The use of different cases is related to the conceptualization of Time. Although, there is no abundance of time expressions in the Mycenaean documents, the words for 'day', 'month', 'year' are attested and it has been observed that, just as in the Post-Mycenaean period, time expressions can be in genitive, dative-locative, accusative. In addition, on some of the tablets, when the date is specified with a month name, phrases that consist of forms that, cannot be easily explained as forms of the same case are used.

The aim of this paper is to discuss and re-evaluate the meaning of the time expressions (consisting of nouns, nominal phrases or adverbs) found on the Linear B tablets, in terms of Time conceptualization. Furthermore, the evidence from the Mycenaean period is compared with relevant forms from the Post-Mycenaean period in order to deepen our understanding of the diachrony of the time expressions in the Greek language.
\end{abstract}

Key words: TIME EXPRESSIONS, MYCENAEAN GREEK, SEMANTIC ROLE

In the Post-Mycenaean period of the Greek language, time expressions consisting of a noun or a nominal phrase can take the genitive, dative-locative, accusative and even nominative case. The use of a different case corresponds to a different question: When? How long? How often? Since when? Until when? And to the nature of the event, described by the time expression: Is it a single or repeated event? Is it defined as regards the length of time or not? Is it restricted within the length of time? Is there oneto-one correspondence between the event and the temporal expression or not? ${ }^{1}$

\footnotetext{
${ }^{1}$ According to G. Coulter (2014, 7-25) what is important for understanding the use of time expressions is the nature of the event, whose temporal location is specified with the particular time expression. The event can be single, of a punctual, durative or limitative type and repeated, of a habitual or distributive type. According to M. Haspelmath (1997: 8, 23ff) in order to interpret the meaning of time expressions it is significant to understand the different semantic roles they denote: temporal location (simultaneous, sequential, sequential durative), temporal distance and temporal extent.
} 
It is commonly assumed that Time is conceptualized in terms of Space, ${ }^{2}$ i.e. that the use of different cases to denote Time in time expressions was developed from their use to denote Location, Direction, Source in spatial expressions (Luraghi, 27; Haspelmath, 1-3). Thus, the use of the accusative in time expressions derives from its use to express spatial extension and consequently the accusative typically denotes durative and repeated events (Luraghi, 57; Coulter, 7-8, 60ff.; 304; Schwyzer, 68-70; Chantraine, 45). The use of the dative to express time developed from its use to express location (in connection to its locative value) and consequently the dative denotes a specific point in time, at which a single, punctual event occurs (Schwyzer, 158-159; Chantraine, 81; Coulter, 306-307). The use of the genitive in time expressions evolved from its use to denote space, within which (in connection to its partitive value) an event occurs. The genitive therefore describes single events restricted to a point (points) within a length of time (Luraghi, 57; Coulter, 308-309; Schwyzer, 111-113; Chantraine, 58-59). It can be also used to describe single events occurring at a specific point in time, as well as repeated events (Coulter, 310-311). Nevertheless, the analysis of the literary works from the Post-Mycenaean period of the Greek language shows that the use of different cases in time expressions differs from author to author and changes over time. It is also related to the meaning of the prepositions. ${ }^{3}$

The present article focuses on the re-evaluation of the semantic analysis of time expressions (consisting of nouns, nominal phrases or adverbs) found on the Linear B tablets in terms of Time conceptualization and compares the evidence from the Mycenaean period with relevant forms from the Post-Mycenaean period.

Time expressions typically consist of the words for hour, day, night, week, month, year, parts of a day or the names of the days of the week, the names of the months, and the names of the seasons. Only a few words related to Time are found on the Mycenaean Linear B tablets.

The word for day, $\tilde{\eta} \mu \alpha \rho$, is attested in the expression a-mo-ra-ma, recorded twice, on two Knossos tablets, written by the same scribe (103) in an identical context, cf. ko-no-si-jo , to-so , e-te , e-so-to , a-mo-ra-ma VIR 25 (KN Am (1) 600.a) and to-so , a-mini-si-jo , e-te , e-so-to , a-mo-ra-ma VIR 9 (KN Am (1) 601.a). The expression a-mo-ra-ma is an iterative compound adverb, /āmōr-āmar|, created by repetition of the first member $|\bar{a} m \bar{o} r|$, an old collective in -ōr, the second member being substituted by /āmar/, $\tilde{\alpha} \mu \alpha \rho$

${ }^{2}$ The concept of Time is actually structured by the domains of Space and Movement in terms of two metaphors: Time is an entity / an object in motion (Moving Time) and Time is a path / a landscape along/across which the observer is moving (Moving Ego) (Evans, 60 - 62). But, the phenomenon of Time is complex, and recent research demonstrates that it is conceptualized in terms of other domains of human experience as well. According to Evans (2004, 107ff.) Time is associated with the following senses (lexical concepts): duration, moment, instance, event, matrix, agent, measurement system and commodity.

${ }^{3}$ For the use of time expressions in Greek authors see the study conducted by G. Coulter (Coulter, 2014) and for the meaning of the prepositions in time expressions see the work of S. Luraghi (Luraghi, 2003). 
(Leukart, 356-361; Buzalkovska, 12, 66-67, 90; Waanders, 13; EDG : 518). ${ }^{4}$ As regards the reduplication, it can be compared with Ved. áhar-ahar (nom. acc.) and Cypr. a-ma-ti-a-

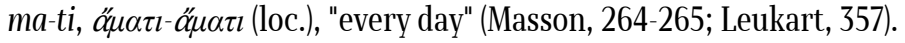

As regards the meaning of a-mo-ra-ma, the morphological repetition implies a temporal repetition and the nominative-accusative can denote duration, "day by day, every day" (Jiménez Delgado, 2016 : 55, 112; Ruijgh, 265). It is obvious from the context that this adverb refers to the activity conducted by the groups of men, designated as men of Knossos and men of Amnisos respectively. If the forms e-te and e-so-to correspond to $\check{\varepsilon} v \theta \varepsilon v$, "thence, thereupon, thereafter" and Dor. $\check{\sigma} \sigma o v \tau \alpha \iota, 3$ pers. pl. of $\varepsilon \dot{\imath} \mu \dot{u}$, "they will be" (D.Mic. I : 203, 254), the two tablets from Knossos tell us that the men will be thence, every day. But, what does thence refer to? It has been suggested by J. Killen that it refers to the Knossos district - the area immediately surrounding the palace ${ }^{5}$ and that the purpose of the phrase e-te , e-so-to , a-mo-ra-ma was to point out that the men will be present in the Knossos palace to conduct works on a daily basis and will not need bedding (Killen, 141-144). If this interpretation is correct, then the time expression a-mo-ra-ma describes an event that occurs every day, only during the day.

Except for the Cypriot loc. $\ddot{\alpha} \mu \alpha \tau \iota-\ddot{\alpha} \mu \alpha \tau \iota$ there are no other correspondences in Post-Mycenaean Greek for the iterative compound adverb /āmōr-ämar/. The common word for day is $\eta \mu \varepsilon \dot{\varepsilon} \rho \alpha$ (a lengthened form of $\tilde{\eta} \mu \alpha \rho$ ), but $\tilde{\eta} \mu \alpha \rho$ is frequent in Homer, either as a simplex or as a second member of compounds, cf. $\dot{\varepsilon} v v \tilde{\eta} \mu \alpha \rho, \dot{\varepsilon} \xi \tilde{\eta} \mu \alpha \rho, \alpha \dot{v} \tau \tilde{\eta}-$ $\mu \alpha \rho, \pi \sigma \sigma \sigma \tilde{\eta} \mu \alpha \rho$. The analysis conducted by G. Coulter reveals that the nominative-accusative forms $\tilde{\eta} \mu \alpha \rho$ (82 examples) and $\eta \mu \alpha \tau \alpha$ (54 examples) are predominant (Coulter, 288ff.). Typically, they denote duration and recurrence, often accompanied by the adjectives $\pi \tilde{\alpha} \varsigma, \pi \rho o ́ \pi \alpha \varsigma$, numerals or adverbs pointing to the length of time, cf. $\pi \tilde{\alpha} v \delta^{\prime}$

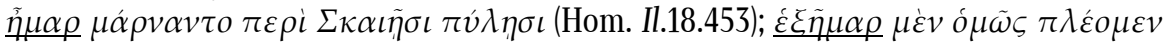

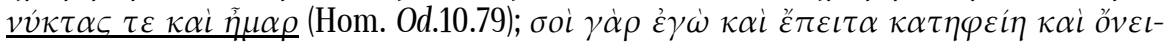

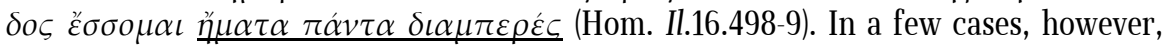

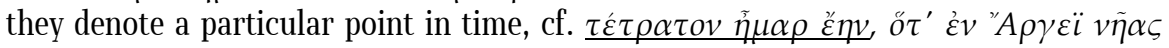

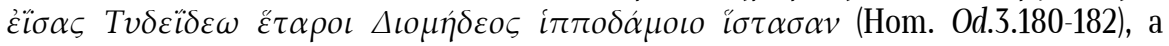
meaning that is otherwise expressed with the dative, cf. $\pi о \lambda \lambda o i ~ \gamma \alpha \dot{\alpha} \rho \rho \omega \omega v \kappa \alpha i$

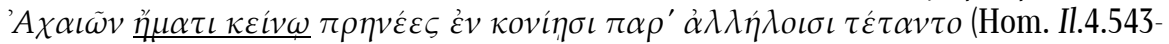
544). The meaning "day by day" and "every day" in the classical authors in the Post-Homeric period is usually expressed by phrases consisting of prepositions and the word for day in the nominative-accusative or in the dative, cf. $\kappa \alpha \tau^{\prime} \eta \mu \alpha \rho$ aici (S. OC. 682) and $\alpha \dot{i} \dot{\varepsilon} v \dot{\varepsilon}^{\prime} \eta^{\prime} \mu \alpha \tau \iota$ (S. OC. 688). But, an expression used in a verse by Theocritus, cf.

\footnotetext{
${ }^{4}$ This interpretation of a-mo-ra-ma was first suggested by H. Mühlestein at the 2nd Cretological Congress in 1966.

${ }^{5}$ This interpretation is not sufficiently precise. Perhaps, it is better to take $e$-te as an adverb in locative, meaning "inside" (Perpillou, see Jiménez Delgado, 2016 : 112, n. 152) or as a common noun, a predicative complement of the verb (Mühlestein, see Waanders, 13).
} 


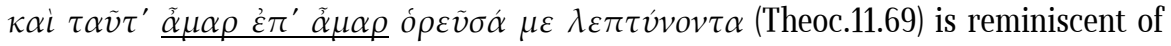
Myc. a-mo-ra-ma.

The word for month, $\mu \dot{\eta} v$ and the particular month names occur in genitive on a number of tablets in Knossos and Pylos. In Knossos, most of the forms are found in the Fp series, which deals with ritual offerings of oil to deities (Doc. ${ }^{2}: 303 f f . ;$ Gulizio, 352ff.). The month name followed (or not) by the genitive singular form me-no, /mēn(n)os/ Att. $\mu \eta v o ́ s$, Boet. $\mu \varepsilon \imath v o ́ s$, Thess. $\mu \varepsilon \imath v v o ́ s$, Lesb. $\mu \tilde{\eta} v v o s$, of the noun $\mu \eta \dot{v} v$, is written at the beginning of the tablet, cf. (1. 1) di-wi-jo-jo 'me-no' qe-ra-si-ja OLE $S$ 1, (1. 2) pa-si-te-o-i OLE $S 1$ (KN Fp (1) 5), / Diwiyoyyo mēn(n)os q. ... OLE S 1, pansi theoihi OLE S 1/, "In the month of Zeus, q. ... $1 \mathrm{~S}$ of oil, to all the gods $1 \mathrm{~S}$ of oil". In the context of the Fp series the name of the month specifies the time when the offerings were made (Duhoux, 259; Gulizio, 352; Ilievski, 212). As Mycenaean documents were usually not dated, it seems that the indicateon of the month was of particular importance to the palace in the case of the ritual offerings (Hiller, 199). The examples from the other Knossos series (Ga, Gg, M, Oa, V), either occur likewise in a clearly religious context, cf. on KN Ga 953, wo-de-wi-jo-jo , / meno [, /Wordēwiyoyyo mēn(n)os/, "In the month of the roses (festival)" in the first line and the phrase pa-si-te-o-i, /pansi theoihi/ "to all the gods" in the line 3a, or are difficult to interpret because the tablet is damaged. Nevertheless, the month name and (or) the word for month in genitive are always written in the first line, at the beginning of the tablet.

In Pylos, month names and the word for month in genitive singular occur in the Fr, Es and Tn series. The Fr series similarly as the Knossos Fp series contains records of ritual offerings of oil (Bennett, 37-38; Bendal, 2ff.), cf. pa-ki-ja-ni-jo-jo me-no , pose-da-o-ne 'pa-ko-we, e-ti-we' OLE+PA Z 2 (PY Fr 1224), /Sphagiyāniyoyyo mēn(n)os Poseidā(h)ōnei sphakowen, e-ti-we OLE+PA Z 2/, "In the month of Sphagiania (festival), for Poseidon, $2 \mathrm{Z}$ of sage-scented e. type of oil". The Tn tablet 316, on which the genitive singular of the month name po-ro-wi-to, /Phlowi(s)tos/ occurs in the first line, cf. po-ro-wi-to-jo also refers to offerings and more precisely to the performance of religious ceremonies including golden vessels and women (Palaima, 450ff.; Duhoux, 322ff.). The name of the month in the Pylos Fr and Tn tablets is always written at the beginning of the document and most likely denotes the time when the offerings and ceremonies took place (Ilievski, 213).

On the other hand, the Pylos Es 650 tablet, on which the month name ki-ri-tijo-jo, perhaps /Krithiyoyyo/, ${ }^{6}$ also occurs in the first line, does not explicitly refer to specific religious activities. It is a record of land-tenure, as it is obvious from the use of the ideogram for wheat and the formula e-ke, to-so pe-mo, /(h)ekhei, tosson spermo/, "holds, so much seed". But, it belongs to a specific set of 15 tablets, the other 14 being records of the contributions, do-so-mo, /dosmos/, of fourteen individuals to the god Poseidon and three other recipients (Doc. ${ }^{2}$ : 276ff.; Del Freo, 166-167; De Fidio, 16-27). The purpose of the tablet Es 650, was most likely an assessment for tribute, which as the tablet PY Es 644 reveals, was due annually, cf. the expression we-te-i-we-te-i (see fur-

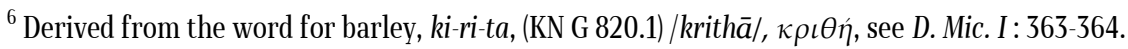


ther). The use of the month name to specify the time when the assessment was made, in view of the nature of the E-series that deals with land-tenure, is isolated and unique (De Fidio, 26-27). Unless we take into account the fact that it was a specific tribute related to religious officials and deities. ${ }^{7}$

There is a common view that the use of the genitive in all these cases is related to the partitive value of the genitive and that it denotes a period of time within which the event happens (Jiménez Delgado, 2016 : 67). Additionally, the occurrence of words such as re-ke-(e)-to-ro-te-ri-jo or to-no-e-ke-te-ri-jo in the Fr series, which may denote festivals and may be interpreted as forms of dative-locative used alongside the names of months in genitive, has been considered as an evidence that the dative-locative case was used to denote moments, whereas the genitive was used to denote periods of time (Bennett, 30). However, if the purpose of the regular use of the month names at the beginning of a document was to indicate the date, then the genitive denotes the point in time at which, rather than the period of time within which, the recorded event and the recording itself took place. The use of the month name in genitive to specify the date has its parallels in the Post-Mycenaean period. The typical dating formula of the inscriptions included the name of the eponymous magistrate and the month name in genitive and the day of the month in dative (McLean, 159-160), cf. $\Theta \iota \circ \delta \omega \rho \omega \dot{\alpha} \rho \chi \tilde{\omega}$,

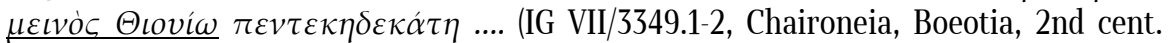

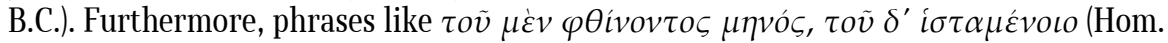
Od. 19.307) were common.

In addition to the phrases where the date is specified with a month name ending in genitive in -o-jo, /-oyyo/, -olo, there is a number of instances on the Linear B tablets where the date is specified with a month name ending in -o with or without the form me-no, cf. in Knossos (1. 1) ka-ra-e-ri-jo / pa-si-te-o-i S 1 (1. 2) qe-ra-si-ja OLE S 1 (KN Fp (1) 6.1) and (l. 1) ka-ra-e-ri-jo , / me-no (1. 2) *56-ti $S$ 2, pa-si-te-o-i $S 1$ (KN Fp (1) 15.1) or in Pylos po-ro-wi-to , wa-na-se-wi-ja OLE+A $S 1$ (PY Fr 1221). Since these are month names that belong to the thematic declension, a concordance between the genitive form me-no and the ending of the month name is expected. This issue has been studied extensively over the course of many years and both phonological and morphological solutions have been considered. Without going into the details of the discussion, ${ }^{8}$ we shall just briefly refer to the relevance of these forms in terms of Time conceptualization. The month names ending in -o when used without me-no, can be interpreted as forms of the nominative, accusative, dative-locative, ablative case. Month names in dative-locative are used on inscriptions from the Post-Mycenaean period of the Greek language, but always

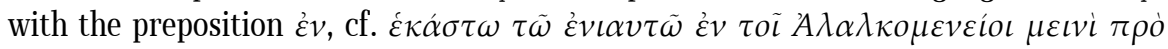

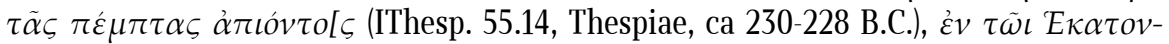

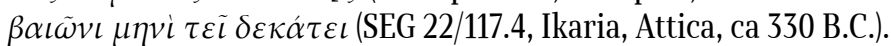

\footnotetext{
${ }^{7}$ For a discussion of other possible interpretations of the form, ki-ri-ti-jo-jo, apart from the one that claims it is a month name, see Del Freo, 2005 : 167ff.

${ }^{8}$ For an up-to-date overview of the problem, see Thompson, 2017 and Jiménez Delgado, 2013.
} 
As to the month names in - 0 used with the word for month, if they are forms in a case other than the genitive singular, one would expect to see me-na (acc.) or me-ne (dat.loc. instr. abl.) instead of me-no. It has been suggested that me-no can also be interpreted as the nominative singular form of the word for month. If so, it would be in accordance with the Mycenaean spelling rules and with the month names in $-0 .{ }^{9}$ This is not impossible. The nominative of rubric was common on the Linear B tablets because of the administrative style of the documents and it is also found on inscriptions from the Post-Mycenaean period, in the dating formula, cf. $\pi \rho v i \tau \alpha v \zeta \Sigma \tau \rho \alpha \dot{\tau} \omega v . \underline{\mu \varepsilon i c \Psi v-}$

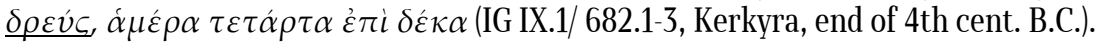

Whichever solution we may choose regarding the case form, the fact remains that the month names in -o with or without me-no occur in the same contexts as the month names in -o-jo. In Knossos, they are always written at the beginning of the tablet, in the first line. In Pylos the only form being po-ro-wi-to, there are variations regarding its position, but nevertheless all of the examples are from the Fr series tablets that deal with offerings. There is no reason to think that these forms denote anything else but the time when the event recorded on the tablet took place. The reason why one and the same scribe, for example the scribe No. 138 in Knossos, used three different variants of the same time expression (month name in -o-jo + me-no, month name in -o + me-no or just month name in -o) to specify the date remains subjective.

With the exception of the occurrences in genitive, the word for month is attested in the expression o-pi-me-ne, a phrase composed of the preposition o-pi, /opi/, or $\pi i$ and /mēn(n)ei/, a dative-locative of $\mu \eta \dot{\eta}$, cf. $\dot{\varepsilon} \pi \iota \mu \eta \dot{v} \iota \varsigma^{\prime}$, "monthly". It is repeated five times (lines 7-11) on the Pylos tablet Fn 7, which deals with the distribution of barley and olives to groups of male workers. The analysis of the figures on the tablet shows that the daily allowances were recorded in the first paragraph, whereas the monthly allowances were recorded in the second paragraph, cf. (1. 3) to]-ko-do-mo HORD [ ] Z 3 VIR 20[ and (1. 11) to-ko-do-mo , o-pi-me-ne [ ] HORD 7 [ ] 5 (Melena, 1996-1997 : 172-173; Chadwick : 73; Bartoněk, 247; Jiménez Delgado, 2016 : 119). The meaning of the time expression in this case would be distributive, as it refers to an event that takes place on a regular basis, every month. In Post-Mycenaean the expression $\kappa \alpha \tau \dot{\alpha} \mu \tilde{\eta} v \alpha$, "monthly, per month"

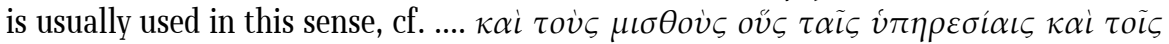

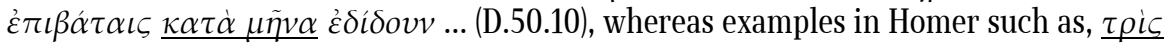

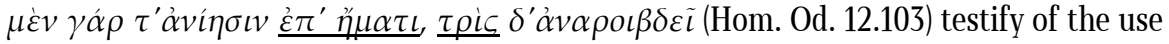
of the preposition $\dot{\varepsilon} \pi i$ with dative-locative accordingly (Coulter, 293, 311).

Finally, the word for month $\mu$ inv occurs in accussative, as me-na on three Knossos tablets that belong to three different series, cf. KN E 842.2; Fs 3.B; Gg (3) 717.1. All three tablets deal with commodities such as olives, honey, wheat, flour and oil. On

\footnotetext{
${ }^{9}$ The scribes would avoid to spell the nominative $\mu \eta \dot{v}$, as *me in order to differentiate it from $M E$, the abbreviation, and would also avoid to spell it as me-na or me-ne in order to differentiate it from the accusative and dative-locative, instrumental-ablative forms, see Jiménez Delgado, 2013: 120 and $2016: 67$.
} 
two of them, there are other words that confirm that these commodities were provided as offerings to gods, cf. te-o-i (KN E 842.1b), /theoihi/ and pa-si-te-o-i (KN Gg (3) 717.1), /pansi theoihi/. On the tablets KN E 842 and Fs 3.B, the form me-na is written immediately before the logograms, whereas on the tablets with similar religious context the genitive form me-no is always written at the beginning of the document. This shows that the semantic role of the time expression in both cases was different. The use of me-na can be compared to the use of the ideogram for month *173, LUNA, cf. KN E 777 and it can be assumed that the accusative form of the word for month denotes a onemonth period (Hajnal, 251; Jiménez Delgado, 2016 : 55). But, were the commodities recorded in these cases provided monthly, every month or were they provided just in that particular case and intended to be sufficient for one month only. It is difficult to deduce from the context whether the time expression in accusative implies only duration within a limited period of time or also a repetition of the activity described. ${ }^{10}$

The word for year, É $\tau o \varsigma$, is attested on the Mycenaean tablets in dative-locative and in accusative. The dative-locative we-te-i-we-te-i, /wetehi wetehi/, cf. Skt. varșe varșe, "every year", occurs 13 times on the Pylos tablet Es 644.1-13, cf. in the first line, ko-pe-re-wo , do-so-mo, we-te-i-we-te-i GRA T 7, /Ko-pe-re-wo dosmos wetehi wetehi GRA T 7|, "K.'s contribution, every year, wheat T 7/. The use of the time expression we-te-i-wete-i on this tablet clarifies that the contributions, recorded in the Pylos Es set of tablets, were due annually, every year. As in the case of a-mo-ra-ma, the morphological repetition denotes the recurrence of the described event, whereas the event itself can be conceived as a single event, because it is a contribution, do-so-mo, /dosmos/ (Lejeune, 234; Del Freo, : 187; Jiménez Delgado, 2016 : 81), but maybe also as an event occurring within

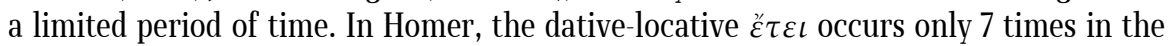
Odyssey, out of which number, 6 in one and the same formula $\eta^{\prime} \lambda v \theta o v \underline{\varepsilon \dot{k} \kappa o \sigma \tau \tilde{\omega} \varepsilon \ddot{\tau} \tau \varepsilon}$ $\dot{\varepsilon} \varsigma \pi \alpha \tau \rho i \delta \alpha \gamma \alpha \tilde{l} \alpha v$, referring to a single event and a particular point in time (Coulter, 295-296).

The accusative of the word for year, we-to, /wetos/ is attested on two Pylos tablets, once on the Ma 365, and eight times on the Aq 64 tablet, always accompanied by a pronominal modifier. The tablet Ma 365 is a record of a tax payment by a group of bronze-smiths, cf. o-da- $a_{2}$, ka-ke-we , $a_{2}$-te-ro , we-to , di-do-si *146 1 RI N 2 ME 10, /o-da- $a_{2}$ khalkēwes, hateron wetos didonsi ...... Although the context of the tablet is simple, there has been a discussion about the phrase in accusative $a_{2}$-te-ro we-to, composed of the

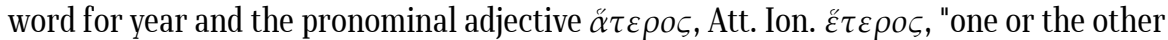
of two, another, different", whether it means "the next year", "every other year" (Doc. ${ }^{2}$ : 294, 536) or "the second year in a row" (Lejeune, 233-234). The first interpretation implies that this tablet records a tax exemption. But, in that case, we would expect the negative form of the verb $\delta i \delta \omega \mu$, "give", o-u-di-do-si, /ou didonsi/, as in the other Ma tablets

\footnotetext{
${ }^{10}$ This is why other possibilities for interpretation of the form me-na have also been taken into account, such as a personal name, a theonym, or even a place name, cf. D.Mic. II : 434.
} 
that record tax exemptions. If the second interpretation is correct, the time expression in accusative denotes duration.

The tablet PY Aq 64 is the first part of a larger document (its second part is the tablet Aq 218), which records the obligations of individual men, marked with the verb

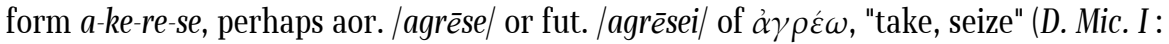
38-39) and the logogram * 171 and the abbreviation ZE. The phrase in accusative to-to , we-to or to-to-we-to, occurs eight times in the lines 2.5.6.7b.13.14.15.16, cf. (1.13) e-ta-wone-u , to-to-we-to , o-a-ke-re-se ZE $1 * 1716$. The form to-to, /totto(d)/ has correspondence in Skt. táttad. It is an iterative compound created with the repetition of the demonstrative stem ${ }^{*} t o$-, and according to M. Lejeune, the repetition denotes distribution (Lejeune, 237-240). The time expression to-to we-to, /totto(d) wetos/ therefore, may be translated "every year", same as we-te-i-we-te-i, /wetehi wetehi/, but it emphasizes the durative aspect of the action expressed with the verbal form a-ke-re-se (Lejeune, 240; Del Freo, 187). Alternatively, to-to we-to has been interpreted as "(during) this year" (Jiménez-Delgado, 2016 : 105, 134-135; Melena, 2001; 27-28). It has to be stressed that to-to we-to is not used with the negative form of $a-k e-r e-s e$, cf. lines 3 and 4 , and when it is used, a-ke-re-se is always preceded by the relative $o$-, $/ h \bar{o}(d) /$. If to-to and $o$ - are in correlation, the phrase toto-we-to o-a-ke-re-se might mean, "that year, in which (when)" or "every year, in which (when)", thus describing the action, not only as recurring on a regular basis, but also as being limited to particular points in time.

The word for year, غ̇ंo is also attested as second member of two compound adverbs, za-we-te (KN Fh 5451.a; PY Ma 225.2a), /kya-wetes/, Post-Myc. $\sigma \tilde{\alpha} \tau \varepsilon \varsigma, \sigma \tilde{\tau} \tau \varepsilon \varsigma$, $\tau \tilde{\eta} \tau \varepsilon \zeta$, a nominative-accusative neuter of an adjective meaning "of this year" (Buzalkovska, 52, 78, 110-111) and au-u-te (KN Od 666.b) /auutes/, cf. Hsch. $\alpha \dot{v} \varepsilon \tau \tilde{\eta} \cdot \alpha \dot{v} \tau o \varepsilon \tau \tilde{\eta}$ and Mes. atavetes, "of the same year, within the year" (Petruševski - Ilievski, 277; Buzalkovska, 52, 78, 111). ${ }^{11}$ The form za-we-te in the Pylos Ma series occurs in the same context as $a_{2}$-te-ro we-to and refers to tax exemption, expressed with the verbal form o-u-di-do-si, whereas in the Knossos Fh series, it describes contribution, a-pu-do-si of oil. The form au-u-te probably refers to the verbal form a-pe-i-si, /apeisi/, a 3rd pers. sing. of ärelul, "go away, depart" (Bartoněk, 324), cf. line b, ]ke-me-no / au-u-te , a-pe-i-si and line a, ] toso o LANA 14. Although only the right half of the tablet KN Od 666, is preserved it is probable that it records a deficit in the expected amount of wool because of the absence of the person designated as ]ke-me-no. Both adverbs za-we-te and au-u-te seem to locate a singular event at a particular point of time, the point of time being a one year period.

Few conclusions emerge as significant from the semantic analysis of the time expressions in Mycenaean Greek. It is obvious that the repetition of morphological elements in time expressions was an important semantic device for marking recurrence of verbal action, cf. a-mo-ra-ma, we-te-i-we-te-i, to-to we-to. In Post-Mycenaean Greek the genitive was used for the same purpose, as well as the phrases in accusative with the

${ }^{11}$ For a different interpretation as an adverb $\alpha \tilde{v} \theta \varepsilon v$ from $\alpha \dot{v} \tau o ́ \theta \varepsilon v$, see Jiménez Delgado, 2016 : 112. 
preposition $\kappa \alpha \tau \alpha \dot{\alpha}$, that is, in order to stress the distributive character of the action, i.e. that its recurrence has a regular cycle. The only time expression with a preposition in Mycenaean Greek is the phrase o-pi-me-ne, and it denotes recurrence on a regular basis. It confirms that the phrases in dative-locative with the preposition $\dot{\varepsilon} \pi \dot{i}$ were used in Post-Mycenaean with the same meaning and in continuity. The genitive, which is probably most versatile of all cases regarding its meaning in time expressions (being used to describe single events restricted to a point (points) within a length of time, or single events occuring at a spefic point in time, or events that recur as something habitual) is attested in the Mycenaean period only in time expressions related to the word for month and month names, always in the same context, i.e. in the same dating formula. This specific use of the genitive has exact correspondence in the dating formula on the inscriptions from the Post-Mycenaean period. The parallel use of forms ending in -0 and forms ending in -0-jo, /-oyyo/ for the month names with thematic stems shows that in Mycenaean, other dating formulas with cases different than the genitive were also used, just like in the Post-Mycenaean period and it also shows that a mixture of two different formulas might have been possible in Mycenaean, just as it was occasionally possible in Post-Mycenaean, cf. $\tau \tilde{\omega} \mu \tilde{\eta} v v o[\varsigma] \tau \tilde{\omega}[T \varepsilon] \rho \varphi \varepsilon i \omega \iota$ (Mytilene, Lesbos, IG XII Suppl./138.38). Although the number of forms is small, it is nonetheless striking that the most common in the time expressions on the Mycenaean tablets is the accusative case, cf. a-mo-ra-ma, me-na, a $a_{2}$-te-ro weto, to-to weto, za-we-te, au-u-te. It is even more striking that only some of these forms clearly denote the duration of the verbal action, whereas for the rest of the forms either the duration is irrelevant, or they describe when the event happened, not how long it lasted. Taking all this into account, it seems that there is room to reconsider the opinion that in the Mycenaean period, the use of different cases to express different semantic roles of time expressions was identical in all aspects as to that in the Post-Mycenaean period. 


\section{References}

Bartoněk, A. (2003). Handbuch des mykenischen Griechisch. Heidelberg : Universitätsver$\operatorname{lag} \mathrm{C}$. Winter.

Bendal, L. M. (1998-1999). A time for offerings. In: J. Bennet and J. Driessen, eds., A-naqo-ta. Studies presented to J. T. Killen. Salamanca : Ediciones Universidad de Salamanca.

Bennett, E. L., Jr. (1958). The Olive Oil Tablets of Pylos. Texts of inscriptions found, 1955. Supl. a Minos Núm. 2. Salamanca : Universidad de Salamanca.

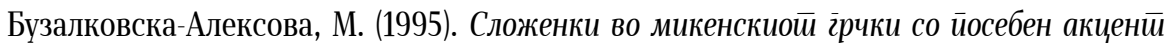

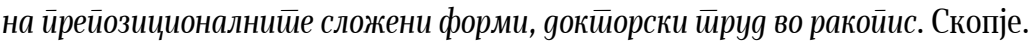

Chadwick, J. (1988). The Women of Pylos. In: J.-P. Olivier and Th. G. Palaima, eds., Texts, Tablets and Scribes. Studies in Mycenaean Economy Offered to Emmett L. Bennett, Jr. Supl. á Minos Núm. 10. Salamanca - Bilbao : Ediciones Universidad de Salamanca Servicio editorial, Universidad del País Vasco Argitarapen Zerbitzua, pp. 43-95.

Chantraine, P. (1953). Grammaire Homérique. Tome II. Syntaxe. Paris : Librairie C. Klincksieck.

Coulter, H. G. (2014). Expressions of Time in Ancient Greek. Cambridge: Cambridge University Press.

De Fidio, P. (1977). I dosmoi Pilii a Poseidon una terra sacra de età micenea. Roma : Edizioni dell'Ateneo \& Bizzarri.

Del Freo, M. (2005). I censimenti di terreni nei testi in lineare B. Pisa - Roma: Istituti editoriali e poligrafici internazionali.

D.Mic. = Aura Jorro, F. (1985-1993). Diccionario Micénico. I-II. Madrid: Consejo Superior de Investigaciones Cientificas.

Doc. $^{2}=$ Ventris, M. and Chadwick, J. (1973). Documents in Mycenaean Greek, 2nd edn. Cambridge : Cambridge University Press.

Duhoux, Y. (2008). Mycenaean anthology. In: Y. Duhoux and A. Morpurgo Davies, eds., A Companion to Linear B. Mycenaean Greek Texts and their World. Volume 1. Louvaine-La-Neuve - Dudley, MA : Peeters, 243-393.

EDG = Beekes, R.S.P. (with the assistance of Lucien Van Beek). (2010). Etymological Dictionary of Greek. I-II. Leiden - Boston: Brill.

Evans, V. (2004). The Structure of Time. Language, meaning and temporal cognition. Amsterdam - Philadelphia: John Benjamin's Publishing Company.

Gulizio, J. (2008). Mycenaean Religion at Knossos. In: A. Sacconi, M. Del Freo, L. Godart and M. Negri, eds., Colloquium Romanum, Atti del XII colloquio internazionale di 
micenologia, Roma, 20-25 febbraio 2006. Pisa - Roma : Fabrizio Serra Editore, pp. 351-358.

Hajnal, I. (1995). Studien zum mykenischen Kasussystem. Berlin - New York: Walter de Gruyter.

Haspelmath, M. (1997). From Space to Time. Temporal Adverbials in the World's Languages. München - Newcastle : Lincom Europa.

Hiller, S. (2011). Mycenaean Religion and Cult. In: Y. Duhoux and A. Morpurgo Davies, eds., A Companion to Linear B. Mycenaean Greek Texts and their World. Volume 2. Louvaine-La-Neuve - Walpole, MA: Peeters, pp. 169-211.

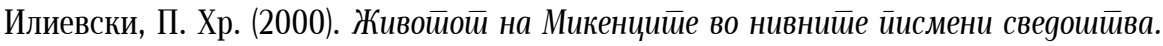
Скопје : МАНУ.

Jiménez Delgado, J. M. (2013). A note on the Mycenaean thematic genitive ending of month names. IF 118, pp. 111-123.

Jiménez Delgado, J. M. (2016). Sintaxis del griego mycénico. Sevilla : Editorial Universidad de Sevilla.

Killen, J. (2000). Two notes on Linear B. ŽA 50, pp. 141-148.

Lejeune, M. (1979 [1997]). Mycénien TO-TO et védique TÁTTAD. In: L. Godart and A. Sacconi, eds. Mémoires de philologie mycénienne IV. Roma : Istituti editoriali e poligrafici internazionali, pp. 233-242.

Leukart, A. (1987). Po-ro-qa-ta-jo, to-sa-pe-mo, a-mo-ra-ma and others: further evidence for Proto-Greek collective formations in Mycenaean and early alphabetic Greek. In: J. T. Killen, J. L. Melena and J-P. Olivier, eds., Studies in Mycenaean and Classical Greek presented to John Chadwick. Minos 20-22. Salamanca : Universidad de Salamanca, pp. 343-365.

Luraghi, S. (2003). On the Meaning of Prepositions and Cases: The expression of semantic roles in Ancient Greek. Amsterdam - Philadelphia: John Benjamins Publishing Company.

Masson, O. (1966). A propos de deux formules redoublées au locatif. ŽA 15.2, 257266.

McLean, B. H. (2002). An Introduction to Greek Epigraphy of the Hellenistic and Roman Periods from Alexander the Great down to the Reign of Constantine (323 B.C.-A.D. 337). Ann Arbor : The University of Michigan Press.

Melena, J. L. (1996-1997). 13 Joins and Quasi-joins of Fragments in the Linear B Tablets from Pylos. Minos 31-32, pp. 171-178.

Melena, J. L. (2001). Textos griegos micénicos comentados. Vitoria-Gasteiz: Eusko Legebiltzarra (Parlamento Vasco).

Palaima, T. G. (1999). Kn 02 - Tn 316. In: Deger-Jalkotzy, S., Hiller, S. and Panagl, O., eds., Floreant Studia Mycenaea. Akten des X. Internationalen Mykenologischen 
Colloquiums in Salzburg vom 1.-5. Mai 1995. Wien : Verlag der Österreichischen Akademie der Wissenschaften, pp. 437-461.

Petruševski, M. D. and Ilievski, P. Hr. (1958). The Phonetic Value of the Mycenaean Syllabic Sign *85. ŽA 8, pp. 265-278.

Ruijgh, C. J. (2011). Mycenaean and Homeric Language. In: Y. Duhoux and A. Morpurgo Davies, eds., A Companion to Linear B. Mycenaean Greek Texts and their World. Volume 2. Louvaine-La-Neuve - Walpole, MA : Peeters, pp. 253-298.

Schwyzer, E. \& Debrunner, A. (1950). Griechische Grammatik, Band II: Syntax und syntaktische Stilistik. München: C. H. Bech'sche Verlagsbuchhandlung.

Thompson, R. J. (2017). The Mycenaean o-stem genitive singular in -o: A re-evaluation. In: M.-L. Nosch and H. Landenius Enegren, eds., Aegean Scripts, Proceedings of the 14th International Colloquium on Mycenaean Studies, Copenhagen, 2-5 September 2015, Vol. II, Roma : Istituto di Studi sul Mediterraeneo Antico (Consiglio Nazionale delle Ricerche), pp. 575-589.

Waanders, F.M.J. (2008). An Analytic Study of Mycenaean Compounds. Structure. Types. Pisa - Roma : Fabrizio Serra Editore. 